\title{
The Leadership of the Principal of Madrasa in Implementing the Madrasa Tsanawiyah Al Ittihadiyah Curriculum Program at Pangkalan Masyhur Medan
}

\author{
Syafaruddin ${ }^{1}$, Salim ${ }^{2}$, \& Hamdan ${ }^{3}$ \\ 1,2,3 Universitas Islam Negeri Sumatera Utara Medan \\ e-mail: *1syafaruddinsiahaan@uinsu.ac.id, 2salim@uinsu.ac.id, 3hamdan@gmail.com
}

\begin{abstract}
This paper aims to explain the principal of the madrasa's leadership in implementing the curriculum program at Madrasa Tsanawiyah Al Ittihadiyah Pangkalan Masyhur Medan. This study used a qualitative method because it revealed madrasa principals' behavior, vice-principal of the madrasa, education staff, and teachers in implementing madrasa curriculum management. For data collection, this study used interview techniques, observation, and document review. The data were collected then analyzed using data reduction steps, data exposure, and concluding. Triangulation techniques were used to ensure the validity of the data, both among participants and between methods. This findings indicated that the madrasa principal's leadership in implementing the curriculum program at MTs Al Ittihadiyah Pkl. Mahsyur is performed effectively. It was indicated by (1) the communication carried out by the principal of the madrasa in socializing the vision, mission, goals, and development of the madrasa curriculum; (2) wise decision making by the principal of the madrasa in curriculum deliberations; (3) exemplary shown by the principal of the madrasa in efforts to develop curriculum; and (4) particular motivation given to teachers in madrasa curriculum development efforts.
\end{abstract}

Keywords: Principal of Madrasa, Leadership, Curriculum.

\begin{abstract}
Abstrak
Tulisan ini bertujuan untuk menjelaskan kepemimpinan kepala madrasa dalam pelaksanaan program kurikulum di Madrasah Tsanawiyah Al Ittihadiyah Pangkalan Masyhur Medan. Penelitian ini menggunakan metode kualitatif, karena di sini diungkapkan perilaku kepala madrasah, wakil kepala madrasah, tenaga kependidikan dan guru-guru dalam pelaksanaan manajemen kurikulum madrasah. Untuk mengumpulkan data digunakan teknik wawancara, observasi, dan kajian dokumen. Data yang dikumpulkan kemudian dianalisis dengan langkah-langkah reduksi data, pemaparan data, dan penarikan kesimpulan. Untuk menjamin keabsahan data, digunakan teknik triangulasi, baik triangulasi antar informan maupun antar metode. Adapun temuan dari penelitian ini menunjukkan bahwa kepemimpinan kepala madrasah dalam pelaksanaan program kurikulum di MTs Al Ittihadiyah Pkl. Masyhur
\end{abstract}


terlaksana secara efektif. Hal ini ditandai dengan (1) komunikasi yang dilakukan kepala madrasah dalam mensosialisasikan visi, misi, tujuan dan pengembangan kurikulum madrasah; (2) pengambilan keputusan yang bijak oleh kepala madrasah dalam musyawarah kurikulum; (3) keteladanan yang ditampilkan kepala madrasah dalam upaya pengembangan kurikulum; dan (4) motivasi khusus yang diberikan kepala madrasah kepada para guru dalam upaya pengembangan kurikulum madrasah.

Kata Kunci: Kepala Madrasah, Kepemimpinan, Kurikulum.

\section{INTRODUCTION}

The implementation of national education in Indonesia is the government's responsibility together with the community (Mas, 2011). Therefore, the government implemented the national education system through education, culture, and religion's ministry. The school system (pre-school, primary school, junior high school, and senior high school) is developed by the education and culture department, while the madrasa and pesantren (Islamic Boarding School) systems are managed and developed by the Religion Ministry. Likewise, there are government-run schools and madrasas, and there are also schools, madrasas, and pesantren run by various mass organizations, foundations, and individuals.

Improving the quality of education in the industrial era 4.0 is necessary to accelerate human resources development (HR) needed to play a strategic role in building world civilization (Ghufron, 2018). Therefore, the effectiveness of education and learning is determined by management and leadership factors, laws and regulations, teachers, education personnel, curriculum, school culture, environment, and the family and socio-economic environment.

Principal leadership is a crucial success factor in curriculum management, including implementing curricular programs and improving teaching quality (Agusthine, et.al., 2009: xvi). Facilitating successful school leadership will support the improvement of student teaching and learning. Moreover, developing a more cohesive leadership system is a promising effort for school principals to improve teaching quality. Therefore, developing an institution or school culture by training the principal will lead to the curriculum program's effectiveness.

As a manager and a leader, the principal is ensured to have the ability to influence educators and education staff to be willing to carry out their primary duties and functions. Every leader has sufficient knowledge and abilities to 
control the institution he leads. The greater his institution's ability and knowledge of affairs is, the stronger his influence will be (Taufiq, 2004: 37). For this reason, the primary key for leaders in carrying out their duties and functions lies in the knowledge and skills of managing the institution.

The principal is the leader of the school community, who is responsible for directing the school in achieving the vision, mission, goals, and targets of the school with the school community, so that the leadership of the principal is a determining factor for the progress or decline of the school (Syafaruddin, 2019: 94). As managers and leaders, the principal influences others to get a job or achieve goals through staff, teachers, and education personnel in various school matters.

Education policies' ability to maintain the higher performance of the education system in schools is an argument for investment in education, and in particular, educational leadership remains strong and attractive (Alfiansyah, et.al., 2020: 52-67; Smither, 2009). While the challenges of education are considerable and the path to reform is complicated, leadership's potential to influence pupils and school performance remain strong (Smither, 2009). Therefore, consistently the quality of leadership is essential in determining teacher motivation and teaching quality in the classroom (Bottery, 2004: xi).

The core problem in schools is improving the quality of learning (Jannah, 2015). In this context, improving the quality of learning is not just increasing the number of teachers or completing facilities and infrastructure (Syafaruddin, et.al., 2020: 32-45). However, school quality changes will be determined by the school principal's leadership and the school principal's leadership will determine the maximum implementation of the curriculum program. That way, the field of management and leadership in curriculum implementation is a matter that must be managed and directed by the principal in achieving learning goals effectively and efficiently.

Principal leadership skills must be qualified, both in the field of decision making and communication (Pradhan \& Chopra, 2008: 4-5), persuade, motivate, facilitate and the most important thing is the example of the principal so that the impact is firm on its members in the school which results in a commitment to realizing the curriculum in quality learning. Leadership characteristics like this always change as transformational leadership behavior (Assingkily \& Mesiono, 2019). The curriculum is the main guideline for implementing formal education 


\section{Fitrah \\ $\rightarrow$ Jurnal Kajian Ilmu-ilmu Keislaman}

Vol. 6 No. 2 December 2020

and learning in schools, madrasas, and Islamic boarding schools. Planning, organizing, program implementation, leadership, and curriculum evaluation are the responsibility of school principals, staff, and teachers in achieving learning effectiveness, mainly to ensure that schools have high performance with the achievement of graduate quality by expectations, vision, mission, and school goals (Smither, 2009).

Performance management efforts are a process of continuous recognition, measurement, and development of individual and group performance and enlightening performance with organizational strategic goals. (Smither, 2009). Various programs, activities, and efforts made by school principals as education managers and leaders to improve the quality of graduates, both in the context of intra-curriculum, extracurricular, and co-curricular. It can be said that the quality of curriculum implementation influences the learning effectiveness, and it is ensured that the success of the curriculum is determined by the professionalism of the teacher who is given the responsibility for implementing learning.

Implementing the school curriculum is determined mainly by the school principal's leadership (Usman \& Raharjo, 2013). Especially in the curriculum development context, leadership is a significant factor because it is a source of power and influence in exercising creativity and inspiration to bring about qualitative changes in schools. Curriculum development is directed towards qualitative new changes that require policies and programs of creative and innovative value. It takes a clear vision, mission, and goals from the principal to take constructive value in realizing student learning (Syafaruddin, 2015: 78; Assingkily, 2020: 140-148).

Schools will be able to achieve qualitative and constructive change when they have quality leadership. Indeed professional leadership is based on experience, education, and skills. That way, educational leadership becomes the central pillar in improving the quality and advancing the nation's civilization and state (Qomar, 2007: 270). The more quality school leadership is, the higher the learning quality will be, and graduates' quality will be superior.

Al Ittihadiyah is an Islamic mass organization that focuses on missionary development, education, and social development established in Medan City, as Islamic organizations similar to Al Washliyah, Muhammadiyah, and Nahdatul Ulama. Apart from being a da'wah organization, all of these organizations make strategic contributions in supporting the government's efforts to educate the 
nation's life. The intention of establishing Al Ittihadiyah was to carry out the Islamic religion's demands and carry out Islamic ideals in public and state affairs.

To achieve this goal, Al Ittihadiyah strives for organizational efforts, especially in Islamic universities, until now (Siddik \& Ja'far, 2017: 48). Therefore, so far, there have been at least 20 academic units developed by Al Ittihadiyah in Medan City. At least, several educational units are being developed, such as Madrasa Diniyah Awaliyah (currently called Madrasa Diniyah Takmiliyah / MDTA), Raudhatul Athfal, Kindergarten, Madrasa Ibtidaiyah, Elementary School, Tsanawiyah, SMP, SMA, Madrasa Aliyah, and SMK, also The College of Tarbiyah Science Al Ittihadiyah (STIT) which developed the PGMI study program, and PIAUD in North Labuhanbatu which was founded in 2017.

At the Al Ittihadiyah foundation, Pangkalan Masyhur Medan, managed an academic unit from Madrasa Diniyah, Raudhatul Athfal, Tsanawiyah, and Madrasa Aliyah. The leadership of the madrasa principal influences the dynamics of the Al Ittihadiyah madrasa in Medan. On the one hand, the principal's existence is to play an educational leadership role while simultaneously displaying religious leadership's profile and characteristics. It is a unique phenomenon displayed by the principal of the madrasa/school at the $\mathrm{Al}$ Ittihadiyah Pangkalan Masyhur school in Medan. One madrasa principal only handles Madrasa Tsanawiyah and Madrasa Aliyah Al Ittihadiyah in Pangkalan Masyhur, Medan city. However, this madrasa has about 800 students, which is increasing from year to year. While his Aliyah madrasa students also reached around 200 people in their third year. Various curriculum development policies, mostly the tahfiz curriculum, strengthening English and Arabic, and extracurricular activities were developed at the Tsanawiyah Al Ittihadiyah madrasa, Pangkalan Masyhur, Medan.

Previous researchers have not widely discussed studies on leadership and Al-Ittihadiyah and among other things, examining aspects of the principal's leadership style (Faiqoh, 2019; Ghofarudin, 2018), the role of Al-Ittihadiyah educational institutions (Syafaruddin, 2015), and principal communications (Mukmin, 2017). For this reason, it is necessary to carry out further research on leadership and Al-Ittihadiyah as material for the track record and historical records of the development of Al-Ittihadiyah in efforts in the field of education.

The distinction of this research is an effort to analyze the leadership of the principal of a madrasa at one of the Al Ittihadiyah educational institutions, 


\section{Fitrah \\ $\rightarrow$ Jurnal Kajian Ilmu-ilmu Keislaman}

Vol. 6 No. 2 December 2020

namely MTs Al Ittihadiyah Pangkalan Masyhur Medan. Furthermore, this paper examines madrasa principals' leadership in implementing the education curriculum program from 4 (four) aspects: communication, decision-making, exemplary, and behavior and motivation carried out by madrasa principals towards madrasa teachers and "citizens".

\section{RESEARCH METHOD}

This research was conducted using qualitative methods. The use of qualitative methods is relevant because the researcher tries to reveal in-depth the leadership of the principal of the madrasa in implementing the MTs Al Ittihadiyah Pangkalan Masyhur curriculum program in Medan. Data that reveals the leadership behavior of madrasa principals in implementing curriculum programs are data in the form of words to explain madrasa principals' behavior in collaboration with research subjects in decision making, communication, modeling, and motivating teachers in implementing the madrasa curriculum program.

Interviews, observation, and document review were used to collect research data. The use of interviews is intended to determine the madrasa principal's leadership behavior in interpreting teachers and education personnel so that they want to implement the madrasa curriculum program. Likewise, interviews were used to cross-check data from school principals to madrasa deputy principals, teachers, and education personnel so that they can be guaranteed as factual. The observation technique was then used to collect data about various leadership activities and the state of the observed objects related to leading activities and learning activities to implement the madrasa curriculum program. Meanwhile, document review is carried out on various decisions and curriculum documents, or subjects and lesson plans (RPP) and tests for summative and formative exams. Furthermore, data analysis was carried out using data reduction techniques, data exposure, and concluding. A triangulation technique was used to ensure the validity of the data, namely cross-checking.

Based on the explanation above, a simple schematic of the research flow is shown as follows: 


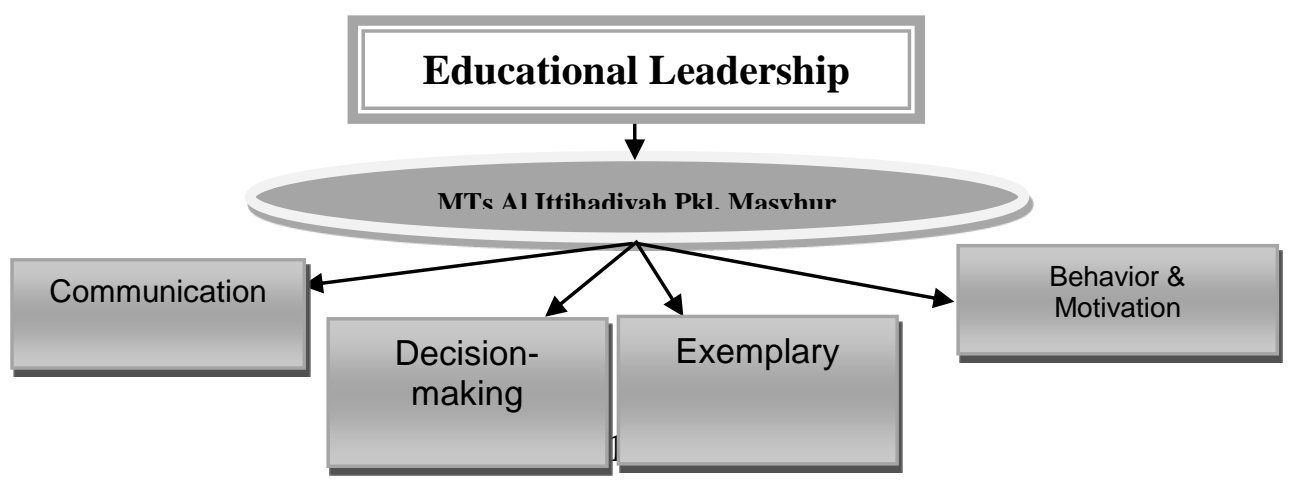

\section{RESEARCH FINDINGS AND DISCUSSION}

\section{Brief Profile of MTs Al Ittihadiyah Pangkalan Masyhur Medan}

Madrasa Tsanawiyah (MTs) Al Ittihadiyah originated from the giving of land as waqf from a servant named $\mathrm{H}$. Saji 'with a size of $18 \times 18 \mathrm{M}$. The land is located at Jalan Karya Jaya Gang Karya VIII No. 7A Pangkalan Masyhur Medan.

In $1982 \mathrm{AD}$, the donated land was handed over to the community through several people appointed by the community as Nazirs who was entrusted with managing the land, namely Alm. KH. Nawawi, Alm. H. Hasan Tanjung and H. Iwan Kliwon.

In that same year, the donated land was built by a community self-help Madrasa, which only had loose walls, and the students were brought from the Al Munawaroh Musholla to now the Al Munawaroh Mosque, which is on Jalan Karya Utama Pangkalan Masyhur Medan.

The Nazirs also served as administrators of Al Ittihadiyah, then later they named the Madrasa with the name Madrasa Ibtidaiyah Al Ittihadiyah now Madrasa Diniyah Takmiliyah Awaliyah (MDTA) Al Ittihadiyah.

Along with the development of this Madrasa, in 1996, the management opened a Madrasa for the Tsanawiyah level, and the principal of the Madrasa was Al Ustaz H. Hamdan Yazid, S.Ag until 2006; because of his busy schedule, the management then dismissed Hamdan Yazid with respect and appointed Pamonoran Siregar, M.Pd.I. as the Principal of Madrasa Tsanawiyah Al Ittihadiyah until now with 822 students.

The existence of MTs. Al-Ittihadiyah Pkl. Masyhur Medan has overgrown with the building of a 5th-floor madrasa building. The construction of this building is based on limited land, while the number of students continues to grow every year. The NSM of this madrasa is 121212710062, while the NPSM is 60727923. The Operational Permit Number: 932 of 2016, dated June 2, 2016, with 


\section{Fitrah \\ Jurnal Kajian Ilmu-ilmu Keislaman}

Vol. 6 No. 2 December 2020

Madrasa accreditation ranked "B" in 2012. However, currently, MTs Al Ittihadiyah Pangkalan Masyhur had accredited A in 2019. MTs Al Ittihadiyah is located on Jalan Karya Jaya Gang Karya VIII No. 7A, Pangkalan Masyhur Urban Village, Medan City, North Sumatra Province, with a Tel. (061) 7876600, and NPWP 21.110.658. 8-121.000. MTs Al Ittihadiyah is currently led by the madrasa principal, namely Pamonoran Siregar, M.Pd.I. The Al Ittihadiyah Foundation with notary Irham Kasymir, SH, S.PN, who issued number 01 dated October 13, 2015, the land certificate area's status is $508 \mathrm{~m}^{2}$, and the building area is $370 \mathrm{~m}^{2}$.

MTs Al Ittihadiyah Pangkalan Masyhur Medan's vision is: "Excellence in achievement, which is based on IMTAQ and science and technology. The achievement of this vision is carried out by carrying out the mission of the institution, namely: (1) Implementing strict rules and regulations; (2) Carry out effective learning and guidance activities; (3) Carry out administrative administration in an orderly manner; (4) Carry out guidance and counseling to students; (5) Carry out library processing; (6) Fostering the potential of students according to their talents; (7) Increasing the quality of competitive graduates; (8) Establishing harmonious cooperation among madrasa members, communities and related institutions in improving the quality of graduates; (9) Improve student skills through productive and extracurricular activities; and (10) Improving quality learning facilities and infrastructure on an ongoing basis.

The madrasa has implemented an up-to-date curriculum in the 2013 curriculum form in line with its vision and mission achievement. Likewise, to improve student competence, the madrasa provides facilities for local content activities. An excerpt from the interview with the principal of the madrasa below:

"Planning for curriculum development is carried out by making the curriculum from the ministry of religion the main guideline applied in this Aliyah Al-Ittihadiyah madrasa. Meanwhile, Madrasa Tsanawiyah and madrasa have the authority to carry out development in terms of the characteristics of madrassas, namely developing local content with activities of Tahfiz Qur'an, Muhaddasah, and English. It is carried out in order to achieve the goal of improving students' language skills based on the results of the evaluations that have been carried out. "

Efforts to facilitate students with local content activities are essential in implementing the education curriculum program in madrasa. To support this, the principal of madrasa jointly plans the education curriculum program. The following is the information given by Panomoran when interviewed:

"The madrasa curriculum planning is carried out based on the applicable provisions, then the things that have been made are evaluated to 
determine the achievement of the goals of the madrasa. For the teacher level, all aspects of the curriculum are evaluated by the principal of the Madrasa, PKI I in the curriculum, Madrasa Committee, and supervisors who are appointed directly by the ministry of religion. "

The quote above emphasizes an effort by the principal of the madrasa to involve his subordinates in planning the madrasa educational curriculum program. A similar sentiment was also conveyed by the Deputy Principal of Madrasa in the following curriculum fields:

"Planning for curriculum development in this madrasa is Tsanawiyah and Aliyah in which every teacher who teaches at this madrasa to make a curriculum based on the K-13 provisions. The curriculum made by each teacher is checked before getting approval from the Madrasa Principal. After the curriculum is approved, activities to implement the curriculum in class are supervised by the madrash's principal. At the end of the year, an overall evaluation is carried out related to the obstacles and problems faced when implementing learning activities. In compiling the curriculum, it is also accompanied by competent people in preparing the curriculum tools. Several times madrasas have also conducted training activities to make curriculum tools based on predetermined conditions to serve as guidelines or references. "

The interview excerpt above further emphasizes that the education curriculum in madrasa begins with implementing teacher training activities as a provision for independently making and presenting educational curriculum tools, according to guidelines or standard references.

\section{The Communication of Madrasa Principal in Implementing Education Curriculum Program}

Communication is an activity that connects individuals, both individuals and groups (Kusumawati, 2016). In leadership in an educational institution, the principal can ideally interact and communicate well with colleagues and subordinates (Assingkily \& Mesiono, 2019: 147-168; Pradhan \& Chopra, 2008: 45). A good form of communication from the principal of the madrasa as the principal of the institution also has a good impact on the smooth implementation of the educational curriculum program (Fauzi, 2017: 53-64; Aprilana, et.al., 2016).

The principal of the madrasa gives an essential form of communication as a leader, namely communicating the institution's vision and mission because this is the responsibility and duty as a leader (Hernandeni, et.al., 2018; Mufidah, 2017). A similar sentiment was also conveyed by the principal of MTs Al Ittihadiyah Pkl. Masyhur Medan as follows: 
Vol. 6 No. 2 December 2020

"In communicating this vision and mission, it is a leader and one's responsibility in leading. The entire ranks who join this madrasa are the main things in communicating the madrasa's vision and mission. Since 2006, this madrasa's vision and mission have been made to become a madrasa that excels in science, technology, and IMTAQ. One of madrasa's missions is to become a superior madrasa in Medan city with an indication or indicator of the highest number of students, and thank God it has been achieved. The vision and mission of this madrasa is explained to all levels with interest in the madrasa. Even the madrasa's vision and mission are also explained to students' parents by inviting them and explaining what things are to be achieved at this madrasa. Thus, parents can work together well to achieve the goals that have been set. "

Based on the interview quoted above, it is understood that the principal of madrasa considers the communication of madrasa vision and mission as an essential responsibility being conveyed as an effort to introduce the madrasa to interested parties and with the parents of students. It is also seen as a relationship and an effort to foster practical cooperation between madrasas and various parties.

In line with the above, Walid (2008) explained that madrasa principals' skills in establishing good communication with related parties, including committees, teachers, and parents/guardians of students, are an alternative in improving the quality of institutions, graduates, and the quality of learning in madrasa. It shows that managerial communication skills are essential things that a madrasa principal must possess.

Supporting the above, Dedi Mahyudi, when interviewed, explained the following:

"What is done by the principal of the madrasa in communicating the vision, mission, and objectives in implementing the curriculum program is to improve the quality of madrasa graduates by holding meetings with all components in charge of the madrasa. On this occasion, the madrasa's principal conveyed the vision, mission, and goals of the madrasa will be used as a reference for developing and advancing. Then the principal of the madrasa conveyed to the entire teacher council to immediately prepare all the curriculum tools, which would be monitored or discussed in the curriculum field, in this case, PKM I. Furthermore, the madrasa principal also said direct supervision activities would carry out every learning activity by the madrasa's principal. The principal of the madrasa also conveyed to the teacher council that the teachers' performance will 
affect the reward that the principal of the madrasa will give to teachers who have good performance."

In line with the interview above, Siti Khodijah and Prima shared the same thing; the following is an excerpt from the interview:

Siti Khodijah:

"The madrasa principal provides an adequate explanation about the madrasa's vision, mission, and objectives always to be used as an orientation for implementation. Then the madrasa tells the teacher to have a curriculum set before teaching in the classroom; before carrying out teaching activities, the madrasa principal will first see the suitability of the curriculum devices with applicable references, and the madrasa principal also said that all of these curriculum devices will always be supervised according to their current content. carry out teaching activities in the classroom. "

Prima:

"In my experience, the madrasa principal communicates the vision, mission, and objectives of this madrasa by holding meetings for all teachers. The principal of the madrasa also motivated that achieving the level of quality graduates was strongly influenced by the quality of the prepared curriculum. The curriculum made by the teacher will be evaluated at the end of the semester. The madrasa principal also opens opportunities for teachers to convey the obstacles in preparing the curriculum. The principal of the madrasa also sends a teacher board that has useful competence in preparing curriculum tools to assist teachers who need assistance. "

Based on the interview quoted above, it is understood that the principal of MTs Al Ittihadiyah madrasa Pkl. Masyhur Medan shows proficiency in communicating the vision and mission of the institution. It can be seen from various parties' involvement in agreeing on the education curriculum program in madrasa. Support this, Marzuki (2017) mentions that communication is the key point of good cooperation and partnership between madrasa and parents.

The communication made is also a critical aspect observed, and adjustments are made to the K-13 educational curriculum. It is in line with what Mukhlisin conveyed in the following interview excerpt:

"The planning of curriculum development in this madrasa is going well because every teacher must have and adapt the curriculum to K13. Learning implementation activities are always supervised on an ongoing basis. "

The development of a planned "carefully" curriculum is critical to be supervised by the madrasa principal as the institution's principal (Wardani, et.al., 


\section{Fitrah \\ $\rightarrow$ Jurnal Kajian Ilmu-ilmu Keislaman}

Vol. 6 No. 2 December 2020

2016). According to Bahri (2011), this development will impact the essential foothold and achievement of the curriculum objectives applied in madrasa. The aspect of curriculum development with madrasa local content is essential for madrasa's progress (Nasir, 2013). In this context, good communication between the principal of the madrasa and all his colleagues and subordinates is an "absolute tool" to ensure good communication as part of a madrasa principal's leadership.

Communication is an essential point in the realization of madrasa partnerships with various parties. In this context, various weaknesses in implementing the education curriculum in madrasa will be minimized with support and cooperation through good communication applied by the madrasa principal.

Based on the description above, it is understood that the principal's leadership of MTs Al Ittihadiyah Pkl. Masyhur Medan in the form of good communication with various parties. It is indicated by related parties' involvement and mutual agreement in planning the madrasa education curriculum program.

\section{Decision-Making by the Madrasa's Principal in Implementing the Education} Curriculum Program

A policy set by the madrasa is undoubtedly known and approved by the leadership, in this case, the madrasa's principal. The approval mechanism begins with the decision-making by the principal of the madrasa. In this context, decision-making is directed towards implementing the educational curriculum program.

Decision-making is an essential part of the leading implementation of a madrasa principal. The various policies that have resulted originate from the courage of a madrasa principal in making decisions. For that, an acceptable policy starts from a wise decision.

In essence, decision-making by the principal of the madrasa determines tactical, operational, and functional policies in containing the program to be achieved, in this case, the educational curriculum program. The form of policies stipulated includes implementation strategies, problem-solving strategies, and selection of alternative problems to achieve madrasas' goals.

In line with the above, Anwar explained that the decision-making process consists of the planning stage (policies in the form of implementation strategies, problem-solving, and alternative solution options), the implementation stage 
(policies in the form of routine activities, controlling activities, and adjusting to the situation), and the monitoring stage ( policies in the form of monitoring, examination, and assessment) (Anwar, 2014).

The sequence of the decision-making process above shows a policy that is determined systematically and measurably in developing the quality of madrasa. In practice, the principal of MTs Al Ittihadiyah madrasa Pkl. Masyhur Medan briefly explained the decision-making process at the madrasa, following an excerpt from the interview:

"In the decision-making process, a meeting with the teacher, the curriculum development team, the assessment/consideration team from all involved, is held first, then a decision is made. So, indeed in decision making at this madrasa, it implements a deliberation system, and from the results of the deliberations that have been decided, nothing else can be different."

Based on the interview excerpt above, decision-making is carried out systematically and measured by the madrasa principal. To make a decision, the principal of the madrasa implements a deliberation system so that the result is a collective agreement that is recognized and accounted for collectively.

Supporting the above, Dedi and Prima when interviewed, answered the same thing, as stated in the interview excerpt below:

Dedi Mahyudi, M.A.

"The principal of the madrasa makes decisions in implementing curriculum programs to improve the quality of graduates, and is always carried out by deliberation and after the results of the deliberations get an agreement, then the principal of the madrasa makes a decision."

Prima, S.Pd.

"The principal of the madrasa makes decisions in implementing curriculum programs to improve the quality of madrasa graduates, namely based on the provisions that have been enforced and implemented in madrasas based on the provisions given by the Ministry of Religion. Moreover, the principal of the madrasa's decision will be decided first if it has obtained the deliberation results. The principal of the madrasa's decision also considers the madrasa development team's input, including parties, foundations, committees, PKM, and Madrasa supervisors. "

Based on the two interview quotes above, it is understood that in every decision-making, the principal of the madrasa carries out a deliberation system 
so that the various parties involved feel responsible for the decisions that will be taken later.

Supporting this, Fahriana explained that decision-making, if it is based on a deliberative system, will result in practical decisions because this is under Islamic education management's efforts based on the evidence of the al-Qur'an and hadith (Fahriana, 2018: 17-46). In line with this, Sabri (2013) emphasized that deliberation is an effective way for administrators of Islamic education institutions to establish policies and make decisions.

MTs Al Ittihadiyah Pkl implemented the education curriculum. Masyhur Medan can be seen in the following table:

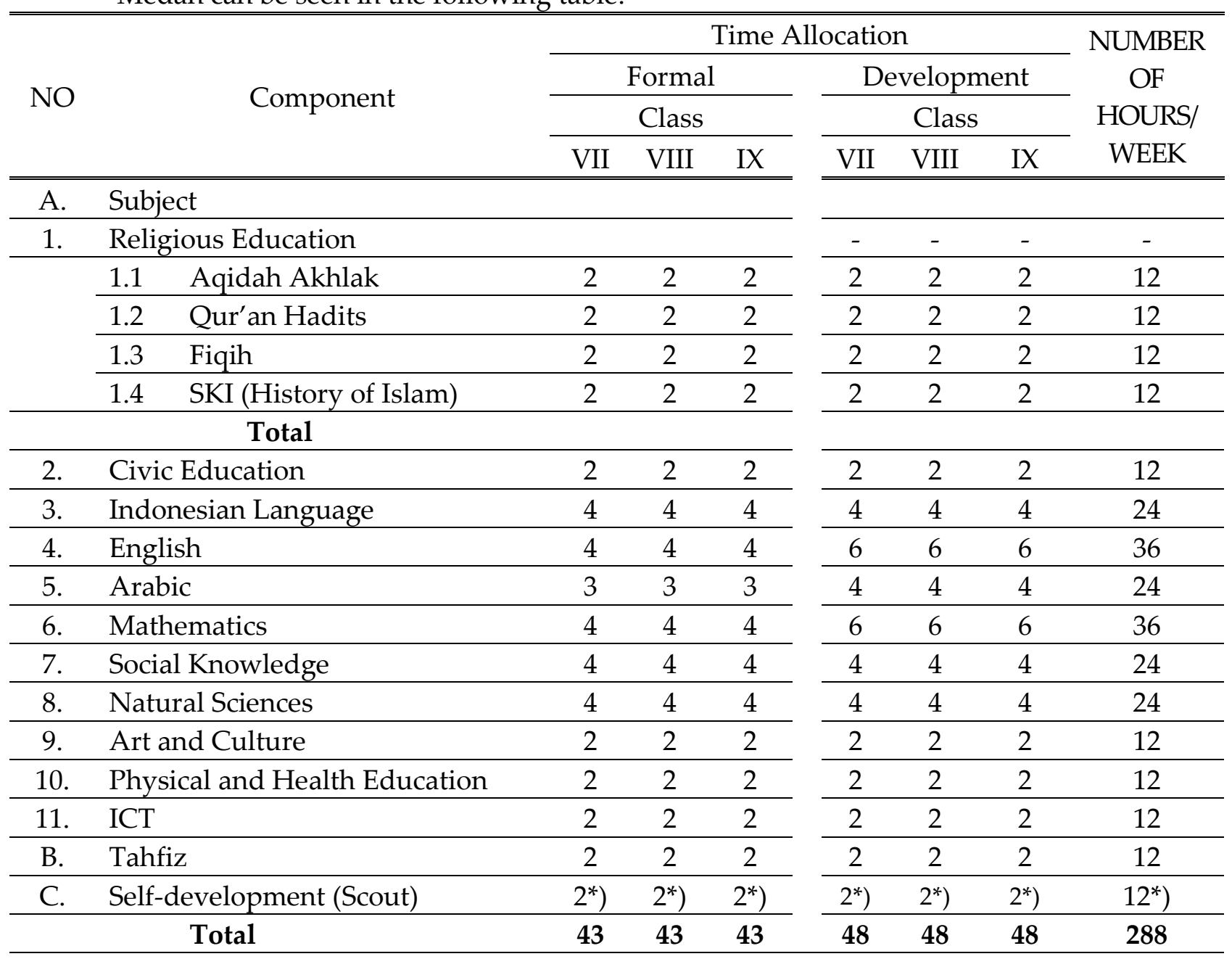

Table 1. MTs Al Ittihadiyah Education Curriculum Pkl. Masyhur Medan

To support the subject matter contained in the curriculum, the madrasa added material in local content and self-development activity form. Based on Permendiknas number 22 of 2005 regarding content standards, it is stated that an 
educational institution must have studies that are local content that is adjusted to regional potential and have a global orientation. Therefore, MTs. Al Ittihadiyah Pkl. Masyhur Medan determines English subjects that specialize in the field of conversation and Arabic subjects in the field of Muhadasah.

Self-development activities at MTs Al Ittihadiyah Pkl. Masyhur Medan aims to provide students opportunities to develop and express themselves according to students' needs, abilities, talents, interests, and the madrasa conditions. The self-development activities are divided into two programs, namely (a) guidance and counseling, including providing personal guidance, conducting class placement tests, conducting home visits, IQ tests, and providing further study guidance; and (b) extracurricular activities, including scouts, speeches, nasyid, daughters, marching bands, pencak silat (Indonesian traditional martil art), dance and tahfizul Qur'an.

Decisions made based on deliberation are seen as approaching mutual benefit. Thus, the decision-making process adopted by the principal of the madrasa as the principal of the institution is the right step in considering the common good for improving the quality of learning and achieving the educational curriculum.

\section{Exemplary Principal of Madrasa in Implementing Educational Curriculum Programs}

Modeling is an essential aspect of the leadership sub-division. A sense of admiration and pleasure for exemplary figures, being a leader quickly moves his subordinates to achieve common goals. In the context of a madrasa, the principal of a madrasa should ideally set an example and make every effort to become an exemplary figure in the madrasa.

The educational curriculum as a corridor for short-term and long-term trips to educational institutions involves various elements and education components in an institution. Efforts to present a "call of the heart" to create a sense of belonging to the madrasa to implement the educational curriculum require exemplary leadership provision. Subordinates voluntarily carry out decisions established as a policy.

According to Manan, the role model aspect is vital to be accustomed to and displayed by the madrasa principal in his daily life within the madrasa and outside the madrasa. Children's skills, morals, and abilities can be strengthened 


\section{Fitrah \\ Jurnal Kajian Ilmu-ilmu Keislaman}

Vol. 6 No. 2 December 2020

through exemplary and habituation (Manan, 2017: 49-65). This example can have a positive influence on the implementation of the educational curriculum in madrasas.

The exemplary aspects applied by the principal of the madrasa are prioritized concerning discipline because, for him, discipline is the main asset for a conducive learning and education process. The following is an excerpt from the interview with the principal of the madrasa:

"So as leaders or Qiyadah, we must be able to be role models. When we also accept exemplary teachers as critical points, all teachers must be role models for their children. Teachers can also be role models for other teachers. For example, as the principal of a madrasa in the application of discipline and curriculum, the principal of a madrasa must do it first. If it is related to discipline, before the madrasa's principle must already exist in that matter and indeed in enforcing discipline, including the principal of the madrasa must continue to carry it out. So the principal will still be punished by the built system, so everyone was treated the same. The things that are always conveyed and always motivated to our teachers should not be just good at talking. Once again, as a leader, he always tries to be an example for the teacher and all students. "

Support the above interview, Suriansyah \& Aslamiah (2015) explained that the principal should ideally partner with teachers, parents, and the community in implementing the educational curriculum. Furthermore, this will positively impact students' character as individual objects that deserve education/education.

Observing the description above, based on Hanifah's information, the principal of the madrasa's good behavior controls and evaluates both, directly and indirectly, related to the teacher's learning at the madrasa. In line with this, Linda also explained the good form given by the principal of the madrasa as stated in the following interview excerpt:

"The exemplary behavior carried out by the principal of the madrasa is applied to the discipline and builds good communication to all teachers and students. The madrasa principal also supervises each class. For students, the madrasa principal also provides a good example; for example, when it is time for Zhuhur prayer, the madrasa's principal immediately invites the students to perform ablution and perform the prayers together." 
The role model given by the principal of the madrasa can help facilitate his duties and responsibilities as a leader. Irawan (2019) argues, exemplary or uswah hasanah is an essential dimension for madrasa principals in improving teacher competence; of course, this has implications for learning and implementing a good curriculum.

Highlight another aspect, Jailani \& Nasution (2017) said that modeling or modeling is very influential in considering a madrasa principal's leadership judgment. As the top leader, the principal of the madrasa will be observed by various parties, especially his subordinates.

Based on the description above, it is understood that the principal should have an exemplary attitude that can be used as a model figure (example) in the institution he leads. In the context of MTs Al Ittihadiyah Pkl. Masyhur Medan, the principal of the madrasa emphasized the importance of discipline as a significant exemplary aspect that needs to be "transmitted" to every "madrasa citizen". Because, through discipline, conductivity to the running of the educational curriculum will be carried out well.

\section{Behavior and Motivation of Madrasa Principals in Implementing Educational Curriculum Programs}

The principal's leadership quality determines the effectiveness of the development of the madrasa principal curriculum. Leadership is needed to bring constructive changes in teaching programs according to the decision maker's values and goals. Teaching is the spearhead of producing quality graduates. Learning must receive greater attention, especially curriculum development, so there is an increased focus on curriculum implementation, which is expected to influence school graduates (Qomar, 2007).

The behavior of "madrasa citizens very much determine efforts to improve curriculum implementation" and the motives that encourage them to carry out activities in madrasa. In this context, the principal should ideally take the initial initiative to display good behavior (exemplary) and have intrinsic motivation to "spread positive energy" to the madrasa community before implementing teachers, education staff, and students.

Dekawati (2018) argues that a madrasa principal's leadership is one of the determining factors for madrasa operations' success. The effectiveness of leadership begins with good behavior displayed by the principal of the madrasa; 


\section{Fitrah \\ Jurnal Kajian Ilmu-ilmu Keislaman}

Vol. 6 No. 2 December 2020

more than that, the principal of the madrasa also provides direction and motivation (verbal and non-verbal) to teachers and students to improve the quality education curriculum in madrasa.

Highlighting other aspects of behavior and giving motivation, the sincerity of work is the primary key in implementing any madrasa program. It will change the framework for educating children in madrassas, from the beginning to think of it as a job, turning into service. (Tahir, 2013). A similar sentiment was conveyed by the principal of MTs Al Ittihadiyah Pkl. Masyhur Medan, when interviewed, the following is an excerpt from the interview:

"In motivating teachers and education personnel to carry out their duties, what we instill is the reward is from Allah, meaning that religious messages are the basis for the principal of the madrasa to work, sincerely and only hope that Allah's Ridho is instilled and motivated. However, that does not mean that the vital thing is sincere, but his work is still given attention. So that teachers are not only oriented towards the value to be accepted."

Based on the quotation above, it is understood that sincerity is the central aspect of planting values in carrying out educational programs in madrasas. Likewise, professionalism in improving quality and addressing various obstacles or obstacles in carrying out the mission and achieving the institution's vision remains the primary concern of madrasa principals. In line with this, Dedi, when interviewed said:

"The principal of madrasa always asks what is the problem when teachers carry out learning activities in the classroom. The principal of madrasa also always provides various inputs related to efforts that can be applied to improve madrasa graduates' quality. "

For supporting efforts to improve the quality of madrasa graduates, teachers are also given teaching and training in the form of workshops and seminars to refresh existing developments. It is as stated by Hanifah when interviewed:

"To motivate teachers, the principal once invited teaching experts by holding workshops and seminars for teachers and others. It is to train teachers to be up to date on current developments."

Prizes as motivation for madrasa teachers accompanied efforts to provide material and refreshment on these developments. The madrasa principal does this regularly and regularly to instill the importance of education and motivation to drive the success of education. It is as conveyed by Prima when interviewed, "One form of motivation given by the principal of the madrasa in implementing curriculum programs is to improve graduates' quality by giving rewards and appreciations for outstanding teachers." 
The behavior and direction of giving motivation by the principal of the madrasa is a positive step in facilitating the implementation of the educational curriculum program at MTs Al Ittihadiyah Pkl. Masyhur Medan. In this context, Sakban, et.al., (2019) views it as a human resource management effort.

The madrasa principal's efforts in behavior by giving motivation are the way to instill a sense of belonging to the madrasa and its management to subordinates as a shared responsibility. Thus, it is understood that giving motivation is an essential part of the leadership aspect applied by the principal of the madrasa in implementing the educational curriculum program at MTs Al Ittihadiyah Pkl. Masyhur Medan.

\section{CONCLUSION}

Based on the explanation above, it can be concluded that the principal of the madrasa's leadership in implementing the curriculum program at MTs Al Ittihadiyah Pkl. Masyhur is performed effectively. It is indicated by (1) the communication carried out by the principal of the madrasa in socializing the vision, mission, goals, and development of the madrasa curriculum. The applicable forms are the efforts of (1) the principal of the madrasa to involve various parties in planning educational curriculum programs that are following the vision and mission of the institution; (2) wise decision making by madrasa principals in curriculum deliberations; (3) exemplary shown by the principal of the madrasa in curriculum development efforts, which is shown through priority aspects of discipline in the madrasa environment; and (4) particular motivation given by the principal of the madrasa to teachers in the development of the madrasa curriculum, while the form of motivation includes special appreciation and appreciation for high achieving teachers and students, both academic and non-academic achievements.

Based on the findings above, it is hoped that it can become a "new" scientific treasure in Islamic education management, especially in the leadership of the principal of the madrasa. It is intended as a form of manifestation of improving the quality of Islamic education institutions, both in terms of the institution's quality and the quality of graduates. Likewise, further researchers can explore aspects of the foundation leader's leadership in implementing curriculum programs at MTs Al Ittihadiyah Pkl. Masyhur Medan. 
Vol. 6 No. 2 December 2020

\section{BIBLIOGRAPHY}

Agusthine, Chaterine H., et.al., 2009, Improving School Leadership, New Jersey: RAND Education.

Alfiansyah, Muhammad, et.al., 2020, “Kebijakan Internal Madrasah dalam Meningkatkan Mutu Pendidikan di MI Nurul Ummah Kotagede Yogyakarta" Magistra: Media Pengembangan Ilmu Pendidikan Dasar dan Keislaman, No. 11, Vol. 1, 52-67. https://publikasiilmiah.unwahas.ac.id/index.php/MAGISTRA/article/view/ $\underline{3460}$.

Anwar, Herson, 2014, "Proses Pengambilan Keputusan untuk Mengembangkan Mutu Madrasah" Nadwa: Jurnal Pendidikan Islam, No. 8, Vol. 1. http://journal.walisongo.ac.id/index.php/Nadwa/article/view/569.

Aprilana, Emi Ratna, et.al., 2016, “Kepemimpinan Kepala Madrasah dalam Mewujudkan Pembelajaran Efektif di Madrasah Ibtidaiyyah Rahmah ElYunusiyyah Diniyyah Puteri Padang Panjang" Elementary: Islamic Teacher Journal, No. $\quad 4, \quad$ Vol. 1. https://journal.iainkudus.ac.id/index.php/elementary/article/view/1975.

Assingkily, Muhammad Shaleh \& Mesiono, 2019, “Karakteristik Kepemimpinan Transformasional di Madrasah Ibtidaiyah (MI) serta Relevansinya dengan Visi Pendidikan Abad 21" Manageria: Jurnal Manajemen Pendidikan Islam, No. 4, Vol. 1. https://doi.org/10.14421/manageria.2019.41-09.

Assingkily, Muhammad Shaleh, 2020, “Eksistensi Lembaga Pendidikan Al Ittihadiyah di Era Industri 4.0" Buku Pengembangan Lembaga Pendidikan Al Ittihadiyah, (ed. Amiruddin MS, et.al.). Medan: Perdana Publishing. http://repository.uinsu.ac.id/9047/1/ISI\%202.pdf.

Bahri, Syamsul, 2011, "Pengembangan Kurikulum Dasar dan Tujuannya" Jurnal Ilmiah Islam Futura, No. 11, Vol. 1. https://jurnal.arraniry.ac.id/index.php/islamfutura/article/view/61.

Bottery, Mike, 2004, The Challenges of Educational Leadership, London: Paul Chapmanm Publishing.

Dekawati, Ipong, 2018, "Perilaku Kepemimpinan Kepala Madrasah Tsanawiyah Negeri" Jurnal Administrasi Pendidikan, No. 25, Vol. 2. https://ejournal.upi.edu/index.php/JAPSPs/article/view/15647.

Fahriana, Ava Swastika, 2018, “Pengambilan Keputusan Secara Musyawarah dalam Manajemen Pendidikan Islam: Kajian Tematik Al-Qur'an dan Al- 
Hadist" Al-Hayat: Journal of Islamic Education, No. 2, Vol. 1, 17-46. https://www.alhayat.or.id/index.php/alhayat/article/view/16.

Faiqoh, Dwi, 2019, “Gaya Kepemimpinan Kepala Madrasah di Madrasah Tsanawiyah Al Ittihadiyah 01 Kalijurang dan Al Ittihadiyah 02 Galuh Timur Tonjong Brebes" Tesis. Purwokerto: IAIN Purwokerto. http://repository.iainpurwokerto.ac.id/6075/.

Fauzi, Ahmad, 2017, “Kepemimpinan Kepala Madrasah dalam Mengembangkan Lembaga Pendidikan Islam" Nidhomul Haq, No. 2, Vol. 2: 53-64. http://ejournal.ikhac.ac.id/index.php/nidhomulhaq/article/view/22.

Ghofarudin, Budi, 2018, "Gaya Kepemimpinan Kepala Madrasah di MTs Al Ittihadiyah 02 Galuh Timur Tonjong Brebes" Tesis. Purwokerto: IAIN Purwokerto. http://repository.iainpurwokerto.ac.id/3438/.

Ghufron, M. A, 2018, “Revolusi Industri 4.0: Tantangan, Peluang dan Solusi Bagi Dunia Pendidikan" Seminar Nasional dan Diskusi Panel Multidisiplin Hasil Penelitian $\mathcal{E}$ Pengabdian Kepada Masyarakat, Jakarta. http://www.proceeding.unindra.ac.id/index.php/dispanas2018/article/view $\underline{\text { File/73/45 }}$

Hernandeni, Denantia Fema, et.al., 2018, "Intensitas Komunikasi Kepala Madrasah, Guru, dan Tenaga Kependidikan dalam Meningkatkan Mutu Pendidikan" Jurnal Administrasi dan Manajemen Pendidikan, No. 1, Vol. 2. http://journal2.um.ac.id/index.php/jamp/article/view/3394.

Irawan, 2019, "Dimensi Uswah Hasanah Kepala Madrasah untuk Meningkatkan Kompetensi Guru Pendidikan Agama Islam" Al-Tarbiyah: Jurnal Pendidikan (The Educational Journal), No. 29, Vol. 1. http://www.syekhnurjati.ac.id/jurnal/index.php/tarbiyah/article/view/5123.

Jailani, M. Syahran \& Rahmad Nasution, 2017, “Kepemimpinan Kepala Madrasah (Studi Kasus Kepemimpinan Kepala Madrasah di Kabupaten Muaro Jambi Provinsi Jambi)" Madrasah: Jurnal Pendidikan dan Pembelajaran Dasar, No. 9, Vol. 2. http://ejournal.uinmalang.ac.id/index.php/madrasah/article/view/4793.

Jannah, Fathul, 2015, “Inovasi Pendidikan dalam Rangka Peningkatan Kualitas Pembelajaran Melalui Penelitian Tindakan Kelas" Prosiding SEMNAS PS2DMP ULM, No. No $1, \quad$ Vol. 1. https://www.rumahjurnal.net/index.php/PS2DMP/article/view/215.

Kusumawati, Tri Indah, (2016), "Komunikasi Verbal dan Nonverbal" Al-Irsyad, No. 6, Vol. 2. http://jurnal.uinsu.ac.id/index.php/al-irsyad/article/view/6618. 


\section{Fitrah}

$\Rightarrow$ Jurnal Kajian Ilmu-ilmu Keislaman

Vol. 6 No. 2 December 2020

Manan, Syaepul, 2017, “Pembinaan Akhlak Mulia Melalui Keteladanan dan Pembiasaan" Jurnal Pendidikan Agama Islam-Ta'lim, No. 15, Vol. 1, 49-65. http://jurnal.upi.edu/file/05 PEMBINAAN AKHLAK MULIA Manan1.pdf.

Marzuki, 2017, “Kemitraan Madrasah dan Orangtua dalam Menanamkan Kedisiplinan Ibadah Siswa MA Asy-Syafi'iyah Kendari" Al-Ta'dib: Jurnal Kajian Ilmu Kependidikan, No. 10, Vol. 2. http://ejournal.iainkendari.ac.id/altadib/article/view/630.

Mas, Sitti Roskina, 2011, "Partisipasi Masyarakat dan Orangtua dalam Penyelenggaraan Pendidikan" El-Hikmah, No. 8, Vol. 2. http://ejournal.uinmalang.ac.id/index.php/elhikmah/article/view/2243.

Mufidah, Nurul, 2017, "Peran Manajer Kepala MIN Jejeran Bantul dalam Implementasi Manajemen Berbasis Madrasah" Manageria: Jurnal Manajemen Pendidikan Islam, No. 2, Nol. https://doi.org/10.14421/manageria.2017.21.03.

Mukmin, Abdul, 2017, “Komunikasi Kepala Madrasah dalam Meningkatkan Prestasi Belajar Siswa Studi Kasus di Madrasah Tsanawiyah Al-Ittihadiyah Medan" Tesis. Medan: UIN Sumatera Utara Medan. http://repository.uinsu.ac.id/1864/1/TESIS\%20pdf\%2C\%20ABDUL\%20MUK MIN\%2COK.pdf.

Nasir, Muhammad, 2013, "Pengembangan Kurikulum Muatan Lokal dalam Konteks Pendidikan Islam di Madrasah" Hunafa: Jurnal Studia Islamika, No. 10, Vol. 1. https://doi.org/10.24239/jsi.v10i1.12.1-18.

Pradhan, N. \& Niti Chopra, 2008, Communication Skills for Educational Managers. Jaipur, India: Book Enclave.

Qomar, Mujammil, 2007, Manajemen Pendidikan Islam. Surabaya: Erlangga.

Sabri, Ahmad, 2013, “Kebijakan dan Pengambilan Keputusan dalam Lembaga Pendidikan Islam" Al-Ta'lim Journal, No. 20, Vol. 2. http://dx.doi.org/10.15548/jt.v20i2.34.

Sakban, et.al., 2019, “Manajemen Sumber Daya Manusia" Alignment: Journal of Administration and Educational Management, No. 2, Vol. 1. https://doi.org/10.31539/alignment.v2i1.721.

Siddik, Dja'far \& Ja'far, 2017, Al Ittihadiyah Delapan Dasawarsa Menerangi Nusantara. Medan: Perdana Publishing. 
Smither, James W, 2009, Performance Management, (Putting Research in Action). Amerika Serikat: Jossey Bass.

Sumarto, 2017, "Kepala Madrasah Transformatif" Tadbir: Jurnal Studi Manajemen Pendidikan, No. $\quad 1, \quad$ Vol. 1. http://journal.iaincurup.ac.id/index.php/ISMPI/article/view/177.

Suriansyah, Ahmad \& Aslamiah, 2015, "Strategi Kepemimpinan Kepala Sekolah, Guru, Orangtua, dan Masyarakat dalam Membentuk Karakter Siswa" Cakrawala Pendidikan: Jurnal Ilmiah Pendidikan, No. 34, Vol. 2. https://doi.org/10.21831/cp.v2i2.4828.

Syafaruddin, 2015, Manajemen Organisasi Pendidikan Islam. Medan: Perdana Publishing.

Syafaruddin, 2015, “Memperkuat Peran Lembaga Pendidikan Al Ittihadiyah dalam Pengembangan SDM Bangsa" dalam Buku Kontribusi Ormas Islam dalam Mewujudkan Umat Islam Berkeunggulan di Abad ke-21, ed. Usiono \& Ahmad Syukri Sitorus. Medan: Perdana Publishing. http://repository.uinsu.ac.id/3475/1/KONTRIBUSI\%20ORMAS\%20ISLAM\% 20-\%201.pdf.

Syafaruddin dan Asrul, 2017, Kepemimpinan Pendidikan Kontemporer. Bandung: Citapustaka Media.

Syafaruddin, 2019, Kepemimpinan Pendidikan. Depok: Rajawali Pers.

Syafaruddin, et.al., 2020, "Manajemen Pembelajaran Pendidikan Agama Islam di SDIT Bunayya Pandan Kabupaten Tapanuli Tengah" Auladuna: Jurnal Pendidikan Dasar Islam, No. 7, Vol. 1, 32-45. http://repository.uinsu.ac.id/id/eprint/8966.

Tahir, M., 2013, “Peranan Kepala Madrasah Aliyah dalam Meningkatkan Kinerja Guru pada Ma'had Darud Da'wah Wal-Irsyad di Pangkajene Sidrap" Praja: Jurnal Ilmiah Pemerintahan, No. 2, Vol. 3. http://jurnal.umsrappang.ac.id/praja/article/view/117.

Taufiq, Ali Muhammad, 2004, Praktik Manajemen Berbasis Al-Qur'an. Jakarta: Gema Insani Press.

Usman, Husaini \& Nuryadin Eko Raharjo, 2013, “Strategi Kepemimpinan Pembelajaran Menyongsong Implementasi Kurikulum 2013" Cakrawala Pendidikan, No. 32, Vol. 1. 


\section{Fitrah}

A Jurnal Kajian Ilmu-ilmu Keislaman

Vol. 6 No. 2 December 2020

Walid, Muhammad, 2008, “Keterampilan Manajerial Kepala Madrasah/Sekolah dalam Meningkatkan Mutu Lulusan" Madrasah: Jurnal Pendidikan dan Pembelajaran Dasar, No. 1, Vol. 1. http://ejournal.uinmalang.ac.id/index.php/madrasah/article/view/1858.

Wardani, Nur Widia, et.al., 2016, "Perencanaan Pengembangan Kurikulum pada Kulliyatul Mu'allimien Al-Islamiyah" Jurnal Pendidikan: Teori, Penelitian, $\mathcal{E}$ Pengembangan, No. 1, Vol. 5. http://dx.doi.org/10.17977/jp.v1i5.6303. 